\title{
VISI KEPALA SEKOLAH SEBAGAI PENGGERAK MUTU PENDIDIKAN
}

\author{
Edi Harapan \\ Dosen Program Studi Manajemen Pendidikan PPs UPGRI Palembang \\ e-mail: dr.edi.harapan@gmail.com
}

\begin{abstract}
The low quality of school was based on the role of teachers and headmaster. The leadership of headmaster is an important one to upgrade the quality of school. To improve the quality education, the headmaster should have a clear vission which is oriented to the quality of school. The continuous professional development of headmaster should be applied. The professional headmaster will understand the needs of education. Through the vission of headmaster as the operator of education will solve the low quality of school.
\end{abstract}

Keyword: Leadership, Headmaster, Vission, Quality of School.

\section{PENDAHULUAN}

Kepala Sekolah merupakan sosok penentu dalam pengembangan pendidikan di tingkat persekolahan. Dari deretan birokrasi yang terkait dengan kiprah pendidikan, kepala sekolah memiliki peran sebagai pelaksana dari semua program pendidikan yang direncanakan oleh Pemerintah Pusat sampai ke tingkat operasional di sekolah. Dengan tidak menyepelekan peran tenaga pendidik dan kependidikan lainnya, maju mundurnya pendidikan sangat ditentukan oleh pola kepemimpinan kepala sekolah dalam mengimplementasikan visi pendidikan yang akan dicapai oleh sekolahnya.

Lebih jauh lagi, kemajuan pendidikan di suatu Negara dapat dilihat dari peningkatan Indeks Pembangunan Manusianya (IPM). Khusus untuk Indonesia, Indeks Pembangunan Manusia (Human Development Index) Indonesia telah mengalami kemajuan dibandingkan beberapa tahun yang lalu. Meskipun kemajuannya tidak terlalu signifikan jika dibandingkan dengan Negara berkembang lainnya. IPM Indonesia menempati peringkat ke 108 dari 187 negara, dengan nilai indeks 0,684 (Data terbaru dari UNDP, 2015). Jika dihitung dari sejak tahun 1980 hingga 2014, IPM Indonesia mengalami kenaikan 44,3 persen. Peringkat IPM, diukur dari capaian pendidikan, kesehatan, dan penghasilan perkepala yang menunjukkan bahwa indeks pengembangan manusia Indonesia makin meningkat.

Akan tetapi, meskipun IPM terus mengalamai peningkatan, disisi lain mutu pendidikan belum mengalami kemajuan. Menurut survei Political and Economic Risk Consultant (PERC), kualitas pendidikan di Indonesia berada pada urutan ke-12 dari 12 negara di Asia. Posisi Indonesia berada di bawah Vietnam. Data yang dilaporkan The World Economic Forum Swedia (2015), 
Indonesia memiliki daya saing yang rendah, yaitu hanya menduduki urutan ke-69 dari 76 negara yang disurvei di dunia. Sementara untuk kualitas para guru, Indonesia berada pada level 14 dari 14 negara berkembang di dunia. Masih menurut survei dari lembaga yang sama, Indonesia hanya berpredikat sebagai follower bukan sebagai pemimpin teknologi dari 53 negara di dunia.Peringkat umum pada bidang matematika, sains pada anak usia 15 tahun dicapai oleh Singapore yang menempati ranking pertama. Negara yang menduduki rangkin pertama pada potensi pertumbuhan ekonomi adalah Negara Ghana dengan angka 3.881.

Potret kualitas pendidikan Indonesia yang rendah itu juga ditunjukkan data Balitbang (2003) bahwa dari 146.052 SD di Indonesia ternyata hanya delapan sekolah saja yang mendapat pengakuan dunia dalam kategori The Primary Years Program (PYP). Dari 20.918 SMP di Indonesia ternyata juga hanya delapan sekolah yang mendapat pengakuan dunia dalam kategori The Middle Years Program (MYP) dan dari 8.036 SMA ternyata hanya tujuh sekolah saja yang mendapat pengakuan dunia dalam kategori The Diploma Program (DP).

Penyebab rendahnya mutu pendidikan di Indonesia tentu tidak lepas dari peran guru dan kepemimpinan seorang kepala sekolah sebagai top leadernya. Melihat pentingnya fungsi kepemimpinan kepala sekolah, maka usaha untuk meningkatkan kinerja yang lebih tinggi bukanlah pekerjaan mudah bagi kepala sekolah karena kegiatan berlangsung dalam sebuah proses panjang yang direncanakan dan diprogram secara baik pula. Untuk mencapai kualitas pendidikan pada sekolah yang dipimpinnya, maka seorang kepala sekolah harus memiliki visi yang jelas dalam memimpin sekolahnya, yaitu visi yang berorientasi kepada mutu pendidikan.

Namun pada kenyataannya tidak sedikit kepala sekolah yang hanya berperan sebagai pimpinan formalitas dalam sebuah sistem alias hanya sekedar sebagai pemegang jabatan struktural sambil menunggu masa purna tugas, jika tidak boleh menyebut mereka sebagai "orang-orang apatis yang kehabisan energi dan gairah hidup". Tidak sedikit pengangkatan seorang kepala sekolah bukan atas dasar prestasi dan kompetensi, tetapi lebih disebabkan adanya hubungan "sebab-akibat" dari pejabat atau kepala daerahnya.

\section{MUTU PENDIDIKAN DI SEKOLAH}

Salah satu indikator keberhasilan kepemimpinan seorang kepala sekolah diukur dari mutu pendidikan yang dicapai oleh lembaga pendidikan yang dipimpinnya. Dalam konteks pendidikan, pengertian mutu mencakup input, proses, dan output 
pendidikan (Depdiknas, 2001:5), serta outcome.

Input pendidikan adalah segala sesuatu yang harus tersedia karena dibutuhkan untuk berlangsungnya proses. Proses pendidikan merupakan berubahnya sesuatu menjadi sesuatu yang lain dengan mengintegrasikan input sekolah sehingga mampu menciptakan situasi pembelajaran yang menyenangkan (enjoyable learning), mampu mendorong motivasi dan minat belajar, dan benar-benar mampu memberdayakan peserta didik. Output pendidikan merupakan kinerja sekolah yang dapat diukur dari kualitasnya, efektivitasnya, produktivitasnya, efisiensinya, inovasinya, dan moral kerjanya. Outcome pendidikan adalah seberapa besar lulusan dari pendidikan tersebut dapat diterima atau dipakai oleh stakeholders.

Dalam konsep yang lebih luas, mutu pendidikan mempunyai makna sebagai suatu kadar proses dan hasil pendidikan secara keseluruhan yang ditetapkan sesuai dengan pendekatan dan kriteria tertentu (Surya, 2002:12). Proses pendidikan yang bermutu

\section{KEMAMPUAN MENGHADAPI PERUBAHAN}

Berdasarkan konsep mutu pendidikan tersebut maka dapat dipahami bahwa pembangunan pendidikan bukan hanya ditentukan oleh berbagai unsur dinamis yang terdapat di sekolah itu sendiri dan lingkungannya sebagai suatu kesatuan sistem.

Menurut Townsend dan Butterworth (1992:35) dalam bukunya Your Child's Scholl, ada sepuluh faktor penentu terwujudnya proses pendidikan yang bermutu, yakni: (1) keefektifan kepemimpinan kepala sekolah; (2) partisipasi dan rasa tanggung jawab guru dan staf; (3) proses belajar-mengajar yang efektif; (4) pengembangan staf yang terpogram; (5) kurikulum yang relevan; (6) memiliki visi dan misi yang jelas; (7) iklim sekolah yang kondusif; (8) penilaian diri terhadap kekuatan dan kelemahan; (9) komunikasi efektif baik internal maupun eksternal; serta (10) keterlibatan orangtua dan masyarakat. Agar mutu pendidikan di sekolah yang dipimpinnya tetap baik dan bisa ditingkatkan, maka kepala sekolah harus mengarahkan visinya kepada sepuluh faktor tersebut.

terfokus pada penyediaan faktor input pendidikan tetapi juga harus lebih memperhatikan faktor proses pendidikan. Input pendidikan merupakan hal yang mutlak harus ada dalam batas-batas tertentu tetapi 
tidak menjadi jaminan dapat secara otomatis meningkatkan mutu pendidikan (school resources are necessary but not sufficient condition to improve student achievement).

Sejak tahun 2002 hingga saat ini, dunia pendidikan nasional ditandai dengan berbagai perubahan yang datang bertubi-tubi, serempak, dan dengan frekuensi yang sangat tinggi. Belum tuntas sosialisasi perubahan yang satu, datang perubahan yang lain. Beberapa inovasi yang mendominasi panggung pendidikan selama tahun 2002 sampai sekarang, antara lain adalah Pendidikan Berbasis Luas (PBL/BBE) dengan life skills-nya, Kurikulum Berbasis Kompetensi (KBK/CBC), Manajemen Berbasis Sekolah (MBS/SBM), Ujian Akhir Nasional (UAN) pengganti EBTANAS, pembentukan komite sekolah dan dewan pendidikan kabupaten/kota. Setiap pembaruan tersebut memiliki kisah dan problematiknya sendiri, perubahan standar pendidikan nasional, sekolah gratis, perubahan kurikulum, desentralisasi pendidikan, pendidikan karaakter, dan lain sebagainya.

Fenomena yang menarik pada perubahan tersebut umumnya memiliki sifat yang sama, yakni menggunakan kata berbasis (based). Bila diamati lebih jauh, perubahan "berbasis" itu umumnya datang dari atas ke bawah; dari pusat ke daerah; dari pengelolaan di tingkat atas menuju sekolah; dari pemerintah ke masyarakat; dari sesuatu yang sifatnya nasional menuju yang lokal. Istilah-istilah lain yang populer dan memiliki nuansa yang sama dengan "berbasis" adalah pemberdayaan (empowerment) akar rumput (grass-root), dari bawah ke atas (bottom up), dan sejenisnya.

\section{KEMAMPUAN BERINOVASI}

Simak saja label-label perubahan yang dewasa ini berseliweran dalam dunia pendidikan nasional (kadang-kadang dipahami secara beragam): manajemen berbasis sekolah (school based management), peningkatan mutu berbasis sekolah (school based quality improvement), kurikulum berbasis kompetensi (competence based curriculum), pengajaran/pelatihan berbasis kompetensi (competence based teaching/training), pendidikan berbasis luas (broad based education), pendidikan berbasis masyarakat (community based education), evaluasi berbasis kelas (classroom based evaluation), evaluasi berbasis siswa (student based evaluation) dikenal juga dengan evaluasi portofolio, manajemen pendidikan berbasis lokal (local based educational management), pembiayaan pendidikan berbasis masyarakat (community based educational financing), belajar berbasis internet (internet based learning), kurikulum 
tingkat satuan pendidikan (KTSP) dan entah apa lagi.

Supriadi (2002: 17) mengatakan "orang yang mendalami teori difusi inovasi akan segera tahu bahwa setiap perubahan atau inovasi dalam bidang apa pun, termasuk dalam pendidikan, memerlukan tahap-tahap yang dirancang dengan benar sejak ide dikembangkan hingga dilaksanakan”. Sejak awal, berbagai kondisi perlu diperhitungkan, mulai substansi inovasi itu sendiri sampai kondisi-kondisi lokal tempat inovasi itu akan diimplementasikan. Intinya, suatu perubahan yang mendasar, melibatkan banyak pihak, dan dengan skala yang luas akan selalu memerlukan waktu. Suatu inovasi mestinya jelas kriterianya, terukur dan realistik dalam sasarannya, dan dirasakan manfaatnya oleh pihak yang melaksanakannya.

Banyak inovasi pendidikan yang diluncurkan di Indonesia dewasa ini kurang dihayati secara penuh oleh pelaksananya (termasuk kepala sekolah), di samping secara konseptual "cacat sejak lahir", serba tergesagesa, serba instan, targetnya tidak realistik, didasari asumsi yang linier seakan-akan suatu inovasi akan bergulir mulus begitu diluncurkan dan secara implisit dimuati obsesi demi menanamkan "aset politik" di masa depan. Maka sudah barang tentu inovasi model seperti ini mengandung risiko kegagalan yang besar.

\section{KEPEMIMPINAN KEPALA SEKOLAH}

Kepemimpinan merupakan salah satu faktor yang sangat penting dalam suatu organisai karena sebagian besar keberhasilan dan kegagalan suatu organisasi ditentukan oleh kepemimpinan dalam organisasi tersebut. Adapun yang dimaksud dengan kepemimpinan seperti yang dikemukakan oleh James M. Black pada Manajemem: $a$ Guide to Executive Command dalam (Sadili Samsudin, 2006:287) adalah kemampuan meyakinkan dan menggerakkan orang lain agar mau bekerja sama di bawah kepemimpinannya sebagai suatu tim untuk mencapai suatu tujuantertentu.

Sementara Indrafachrudi mengartikan kepemimpinan sebagai suatu kegiatan dalam membimbing suatu kelompok sedemikian rupa sehingga tercapailah tujuan itu. Kemudian menurut Ukas (2004) kepemimpinan adalah kemampuan yang dimiliki oleh seseorang untuk dapat mempengaruhi orang lain, agar ia mau berbuat sesuatu yang dapat membantu pencapaian suatu maksud dan tujuan.

Berdasarkan beberapa definisi di atas dapat disimpulkan bahwa kepemimpinan adalah kemampuan yang dimiliki seseorang dalam mempengaruhi orang lain untuk mau bekerja sama agar mau melakukan tindakan dan perbuatan dalam mencapai tujuan bersama. Kepala sekolah adalah seorang 
pemimpin sekolah atau pemimpin suatu lembaga tempat menerima dan memberi pelajaran. Kepala sekolah adalah seorang tenaga fungsional guru yang diberi tugas untuk memimpin suatu sekolah di mana diselenggarakan proses belajar mengajar, atau tempat di mana terjadi interaksi antara guru yang memberi pelajaran dan murid yang menerima pelajaran (Wahjosumidjo, 2002). Kepala sekolah adalah seorang guru (jabatan fungsional) yang diangkat untuk menduduki jabatan struktural (kepala sekolah) di sekolah (Rahman, 2006). Kepala sekolah adalah sorang guru yang mempunyai kemampuan untuk memimpin segala sumber daya yang ada pada suatu sekolah sehingga dapat didayagunakan secara maksimal untuk mencapai tujuan bersama.

Kepala sekolah merupakan salah satu komponen pendidikan yang paling berperan dalam meningkatkan kualitas pendidikan. Sebagaimana dikemukakan dalam Pasal 12 ayat 1 PP 28 tahun 1990 bahwa kepala sekolah bertanggungjawab atas penyelenggaraan kegiatan pendidikan, administrasi sekolah, pembinaan tenaga kependidikan lainnya, dan pendayagunaan serta pemeliharaan sarana dan prasarana.

\section{KETERCAPAIAN TUJUAN \\ PENDIDIKAN}

Kepala sekolah diangkat melalui prosedur serta persyaratan tertentu yang bertanggung jawab atas tercapainya tujuan pendidikan melalui upaya peningkatan profesionalisme tenaga kependidikan yang mengimplikasikan meningkatkanya prestasi belajar peserta didik. Kepala sekolah yang professional akan berfikir untuk membuat perubahan tidak lagi berfikir bagaimana suatu perubahan sebagaimana adanya sehingga tidak terlindas oleh perubahan tersebut. Untuk mewujudkan kepala sekolah yang professional tidak semudah membalikkan telapak tangan, semua itu butuh proses yang panjang. Namun kenyataan di lapangan masih banyak kepala sekolah yang tidak menjalankan tugas dan fungsinya sebagai pemimpin pendidikan ini disebabkan karena dalam proses pengangkatannya tidak ada trasnfaransi, rendahnya mental kepala sekolah yang ditandai dengan kurangnya motivasi dan semangat serta kurangnya disiplin dalam melakukan tugas, dan seringnya datang terlambat serta banyak faktor penghambat lainnya untuk meningkatkan kualitas pendidikan yang mengimplikasikan rendahnya produktivitas kerja kepala sekolah yang berimplikasi juga pada mutu (input, proses, dan output). 
Ketercapaian tujuan pendidikan sangat bergantung pada kecakapan dan kebijaksanaan kepemimpinan kepala sekolah yang merupakan salah satu pemimpin pendidikan. Karena kepala sekolah merupakan seorang pejabat yang profesional dalam organisasi sekolah yang bertugas mengatur semua sumber organisasi dan bekerjasama dengan guru-guru dalam mendidik siswa untuk mencapai tujuan pendidikan. Dengan keprofesionalan kepala sekolah ini pengembangan profesionalisme tenaga kependidikan mudah dilakukan karena sesuai dengan fungsinya, kepala sekolah memahami kebutuhan sekolah yang ia pimpin sehingga kompetensi guru tidak hanya mandeg pada kompetensi yang ia miliki sebelumnya, melainkan bertambah dan berkembang dengan baik sehingga profesionalisme guru akan terwujud.

Sekolah sebagai pendidikan formal bertujuan membentuk manusia yang berkepribadian, dalam mengembangkan intelektual peserta didik dalam rangka mencerdaskan kehidupan bangsa. Kepala sekolah sebagai pemimpin pada sebuah lembaga pendidikan formal, punya peran sangat penting dan menentukan dalam membantu para guru dan siswanya. Di dalam kepemimpinnya kepala sekolah harus dapat memahami, mengatasi dan memperbaiki kekurangan-kekurangan yang terjadi di lingkunagn sekolah secara menyeluruh. Untuk meningkatkan kualitas pendidikan di sekolah yang dipimpinnya, seorang kepala sekolah harus mampu meningkatkan kinerja para pendidik termasuk tenaga kependidikan yang berada di bawah kewenangannya.

\section{FAKTOR PENGHAMBAT PROSES PENDIDIKAN}

Banyak faktor yang dapat mempengaruhi kinerja seorang guru. Maka sebagai pimpinan tertinggi di sekolah, seorang kepala sekolah harus mampu memberikan energi positif yang mampu menggerakkan para guru untuk melaksanakan tugasnya secara sungguhsungguh dan penuh tanggung jawab sehingga kinerja mereka menjadi lebih baik dan lebih baik lagi. Sebagai pemimpin yang mempunyai pengaruh, seorang kepala sekolah harus terus berusaha agar ide, nasehat, saran dan (jika perlu) instruksi dan perintah serta kebijakannya di ikuti oleh para guru binaannya. Dengan demikian ia dapat mengadakan perubahan-perubahan dalam cara berfikir, dalam bersikap dan dalam bertindak atau berperilaku. Maka menjadi tuntutan bagi seorang kepala sekolah harus selalu merefresh pengetahuan dan wawasan keilmuannya agar nantinya dapat mendukung tugasnya sebagai seorang pimpinan. 
Banyak faktor penghambat tercapainya kualitas kepemimpinan seorang kepala sekolah seperti proses pengangkatannya tidak transparan, rendahnya mental kepala sekolah yang ditandai dengan kurangnya motivasi dan semangat serta kurangnya disiplin dalam melakukan tugas dan seringnya datang terlambat, wawasan kepala sekolah yang masih sempit serta banyak faktor lain yang menghambat kinerja seorang kepala sekolah untuk meningkatkan kualitas pendidikan pada lembaga yang dipimpinnya. Ini mengimplikasikan rendahnya produktivitas kerja kepala sekolah yang berimplikasi juga pada mutu (input, proses dan output).

Dalam melaksanakan fungsi kepemimpinannya, kepala sekolah harus melakukan pengelolaan dan pembinaan terhadap seluruh komponen sekolah melalui kegiatan administrasi, manajemen dan kepemimpinan yang sangat tergantung pada kemampuan manajerial seorang kepala sekolah. Sehubungan dengan itu, kepala sekolah sebagai supervisor berfungsi untuk mengawasi, membangun, mengoreksi dan mencari inisiatif terhadap jalannya seluruh kegiatan pendidikan yang dilaksanakan di lingkungan sekolah. Disamping itu, kepala sekolah sebagai pemimpin lembaga pendidikan berfungsi mewujudkan hubungan manusiawi (human relationship) yang harmonis dalam rangka membina dan mengembangkan kerjasama antar personal, agar secara serempak bergerak kearah pencapaian tujuan melalui kesediaan melaksanakan tugas masing-masing secara bersungguh-sungguh dan bertanggung jawab yang dalam bahasa sekarang dikemas dalam istilah profesional. Oleh karena itu, segala penyelenggaraan pendidikan akan mengarah kepada usaha meningkatkan mutu pendidikan yang sangat dipengaruhi oleh guru dalam melaksanakan tugasnya secara operasional. Untuk itu kepala sekolah harus melakukan supervisi sekolah yang memungkinkan kegiatan operasional itu berlangsung dengan baik.

\section{KEPALA SEKOLAH PROFESIONAL}

Profesionalisme adalah kondisi, arah, nilai, tujuan, dan kualitas suatu keahlian dan kewenangan yang berkaitan dengan mata pencaharian seseorang (Kusnandar, 2007). Profesionalisme merupakan sebutan yang mengacu pada sikap mental dalam bentuk komitmen dari para anggota suatu profesi untuk senantiasa mewujudkan dan meningkatkan kualitas profesionalnya (Surya, 2007). 
Kepala sekolah merupakan salah satu komponen pendidikan yang paling berperan dalam meningkatkan kualitas pendidikan. Oleh karena itu seorang kepala sekolah haruslah orang yang profesional. Secara profesional seorang kepala sekolah memiliki tugas-tugas sebagai berikut.

1. Kepala sekolah berperilaku sebagai saluran komunikasi di lingkungan sekolah yang dipimpinnya. Segala informasi yang berkaitan dengan penyelenggaraan pendidikan di sekolah harus selalu terpantau oleh kepala sekolah.

2. Kepala sekolah bertindak dan bertanggungjawab atas segala tindakan yang dilakukan oleh bawahan. Perbuatan yang dilakukan oleh para guru, siswa, staf dan orang tua siswa tidak dapat dilepaskan dari tanggung jawab kepala sekolah.

3. Dengan waktu dan sumber yang terbatas seorang kepala sekolah harus mampu menghadapi berbagai persoalan. Dengan segala keterbatasan, seorang kepala sekolah harus dapat mengatur pendistribusian tugas secara cepat serta dapat memprioritaskan bila terjadi konflik antara kepentingan bawahan dengan kepentingan sekolah.

4. Kepala sekolah harus berfikir secara analitik dan konsepsional. Kepala sekolah harus dapat memecahkan persoalan melalui satu analisis, kemudian menyelesaikan persoalan dengan satu solusi yang feasible. Serta harus dapat melihat setiap tugas sebagai satu keseluruhan yang saling berkaitan.

5. Kepala sekolah adalah seorang mediator atau juru penengah. Dalam lingkungan sekolah sebagai suatu organisasi di dalamnya terdiri dari manusia yang mempunyai latar belakang yang berbeda-beda yang bisa menimbulkan konflik. Untuk itu kepala sekolah harus jadi penengah dalam konflik tersebut.

6. Kepala sekolah adalah seorang politisi. Kepala sekolah harus dapat membangun hubungan kerja sama melalui pendekatan persuasi dan kesepakatan (compromise). Peran politis kepala sekolah dapat berkembang secara efektif, apabila: (1) dapat dikembangkan prinsip jaringan saling pengertian terhadap kewajiban masing-masing, (2) terbentuknya aliansi atau koalisi, seperti organisasi profesi, OSIS, BP3, komite sekolah dan sebagainya; (3) terciptanya kerjasama (cooperation) dengan berbagai pihak, sehingga aneka macam aktivitas dapat dilaksanakan.

7. Kepala sekolah adalah seorang diplomat. Dalam berbagai forum pertemuan kepala sekolah adalah wakil resmi dari sekolah yang dipimpinnya.

8. Kepala sekolah harus mampu mengambil keputusan-keputusan sulit. Tidak ada satu organisasi pun yang berjalan mulus tanpa masalah. Demikian pula sekolah sebagai suatu organisasi tidak 
luput dari persoalan dan kesulitan-kesulitan. Apabila terjadi kesulitan-kesulitan, kepala sekolah diharapkan berperan sebagai orang yang dapat menyelesaikan persoalan yang sulit tersebut (Wahjosumidjo (2002).

\section{PERAN KEPALA SEKOLAH}

Dalam menjalankan kepemimpinannya, selain harus tahu dan paham tugasnya sebagai pemimpin, yang tak kalah penting dari itu semua adalah seyogyanya kepala sekolah memahami dan mengetahui perannya. Adapun peran kepala sekolah dalam menjalankan peranannya sebagai manajer seperti yang diungkapkan oleh Wahjosumidjo (2002:90) adalah (a) peranan hubungan antar perseorangan; (b) peranan informasional; (c) sebagai pengambil keputusan.

Peranan kepala sekolah sebagai penghubung antar perseorangan atau Figure head yang berarti lambang dengan pengertian kepala sekolah sebagai lambang sekolah; Kepemimpinan (Leadership) artinya kepala sekolah adalah pemimpin yang harus mampu menggerakkan seluruh sumber daya yang ada di sekolah sehingga dapat melahirkan etos kerja dan produktifitas yang tinggi untuk mencapai tujuan; Penghubung (liasion) artinya kepala sekolah menjadi penghubung antara kepentingan sekolah dengan kepentingan lingkungan di luar sekolah. Sedangkan secara internal kepala sekolah menjadi perantara antara guru (pendidik), tenaga kependidikan dan peserta didik (siswa).

Peranan kepala sekolah sebagai informasional atau Kepala sekolah sebagai monitor artinya kepala sekolah harus selalu mengadakan pengamatan terhadap lingkungan karena kemungkinan muncul informasi-informasi baru yang berpengaruh terhadap sekolah yang dipimpinnya; kepala sekolah sebagai disseminator artinya kepala sekolah bertanggungjawab penuh untuk menyebarluaskan dan membagi-bagi informasi kepada para guru (pendidik), tenaga kependidikan serta orang tua siswa; kepala sekolah sebagai spokesman artinya kepala sekolah memiliki tugas menyebarkan informasi kepada lingkungan di luar sekolah yang dianggap perlu.

Peranan kepala sekolah sebagai pengambil keputusan yaitu Enterpreneur artinya kepala sekolah selalu berusaha memperbaiki penampilan sekolah melalui berbagai macam ide dan gagasan pemikiran berupa program-program yang baru serta melakukan survey untuk mempelajari berbagai persoalan yang timbul di lingkungan sekolah; Disturbance handler (orang yang memperhatikan gangguan) artinya kepala sekolah harus mampu mengantisipasi gangguan yang timbul dengan memperhatikan situasi dan ketepatan keputusan yang diambil; A Resource Allocater (orang yang menyediakan segala sumber) artinya kepala sekolah bertanggungjawab 
untuk menentukan dan meneliti siapa yang akan memperoleh atau menerima sumber-sumber yang disediakan dan harus didelegasikan; A negotiator roles artinya kepala sekolah harus mampu mengadakan pembicaraan dan musyawarah dengan pihak luar dalam memenuhi kebutuhan sekolah.

\section{WADAH PEMBINAAN KEPALA SEKOLAH}

Banyak faktor yang dapat menghambat tercapainya kualitas profesional kepemimpinan kepala sekolah, antara lain berkaitan dengan proses pengangkatan seorang kepala sekolah yang tidak transparan, rendahnya motivasi dan etos kerja, kurangnya disiplin dan tanggung jawab dalam melaksanakan tugas, seringnya datang terlambat, sempitnya wawasan kepala sekolah, serta banyak faktor lain.

Wadah-wadah yang telah dikembangkan dalam pembinaan kemampuan profesional kepala sekolah cukup banyak seperti Musyawarah Kepala Sekolah (MKS), Kelompok Kerja Kepala Sekolah (K3S) serta Pusat Kegiatan Kepala Sekolah (PKKS). Disamping itu peningkatan dapat dilakukan melalui pendidikan dengan program sarjana atau pascasarjana bagi para kepala sekolah sesuai dengan bidang keahliannya, sehingga tidak terlepas dari koridor disiplin ilmu masingmasing. Dengan mengefektifkan MKKS semua kesulitan dan permasalahan yang dihadapi oleh kepala sekolah dalam kegiatan pendidikan dapat dipecahkan, dan diharapkan dapat meningkatkan mutu pendidikan di sekolah.

Kelompok diskusi profesi juga sangat penting artinya sehingga perlu dibentuk untuk mengatasi tenaga kependidikan yang kurang semangat dalam melakukan tugas-tugas kependidikan di sekolah. Kelompok diskusi profesi dapat melibatkan pengawas sekolah, komite sekolah atau orang lain yang ahli dalam memecahkan masalah yang dihadapi kepala sekolah dan tenaga kependidikan.

Hal lain adalah tersedianya buku yang dapat menunjang kegiatan sekolah dalam mendorong visi menjadi aksi. Karena akan sangat sulit untuk dapat mengembangkan dan meningkatkan profesionalisme kepala sekolah jika tidak ditunjangkan oleh sumber belajar yang memadai.

Selain itu kepala sekolah harus memiliki visi dan misi, serta strategi manajemen pendidikan secara utuh yang berorientasi kepada mutu. Strategi ini dikenal dengan manajemen mutu terpadu (MMT) atau kalau dunia bisnis dikenal dengan nama total quality management (TQM), yang merupakan usaha sistematis dan terkoordinasi untuk secara terus-menerus 
memperbaiki kualitas layanan. Sedikitnya terdapat lima sifat layanan yang harus diwujudkan oleh kepala sekolah agar "pelanggan" puas; yakni layanan sesuai dengan yang dijanjikan (reliability), mampu menjamin kualitas pembelajaran (assurance), iklim sekolah yang kondusif (tangible), memberikan perhatian penuh kepada peserta didik (emphaty), dan cepat tanggap terhadap kebutuhan peserta didik (responsiveness).

Dalam menumbuhkan kepala sekolah yang profesional dalam paradigma baru manajemen pendidikan di sekolah diperlukan adanya peningkatan disiplin untuk menciptakan iklim sekolah yang lebih kondusif dan dapat memotivasi kerja, serta menciptakan budaya kerja dan budaya disiplin para tenaga kependidikan dalam melakukan tugasnya di sekolah.

\section{KESIMPULAN}

Perkembangan ilmu pengetahuan, teknologi, seni dan budaya ikut merambah dunia pendidikan, sehingga menuntut seorang kepala sekolah yang professional. Untuk itu kepala sekolah dihadapkan pada tantangan untuk melaksanakan pengembangan pendidikan secara terarah dan berkesinambungan. Peningkatan profesionalisme kepala sekolah perlu dilaksanakan secara berkeinambungan dan terencana dengan melihat permasalahan-permasalahan dan keterbatasan yang ada, sebab kepala sekolah merupakan pemimpin pendidikan yang juga bertanggung jawab dalam meningkatkan profesionalisme pendidik (guru) serta tenaga kependidikan lainnya. Kepala sekolah yang professional akan mengetahui kabutuhan dunia pendidikan. Dengan begitu kepala sekolah akan melakukan penyesuaian-penyesuaian agar pendidikan berkembang dan maju sesuai dengan kebutuhan pembangunan serta kemajuan ilmu pengetahuan dan teknologi.

Melalui konsep Visi Kepala Sekolah sebagai penggerak Mutu Pendidikan inilah diharapkan dapat mengatasi masalah rendahnya mutu pendidikan dengan mengoptimalkan segala sumber daya yang terdapat di sekolah. Upaya peningkatan profesionalisme kepala sekolah merupakan proses keseluruhan dan organisasi sekolah serta harus dilakukan secara berkesinambungan karena perubahan yang terjadi selalu dinamis serta tidak bisa diprediksi sehingga kepala sekolah maupun tenaga kependidikan harus selalu siap dihadapkan pada kondisi perubahan. Ada istilah seorang tenaga pendidik yang tadinya professional belum tentu akan terus profesional, bergitupun sebaliknya, tenaga kependidikan yang tadinya tidak professional belum tentu akan selamanya tidak professional. Dari pernyataan itu jelas kalau perubahan akan selalu terjadi dan menuntut adanya penyasuaian sehingga kita dapat mengatasi perubahan tersebut dengan penuh persiapan. 
Dalam upaya peningkatan mutu sekolah dan profesionalisme kepala sekolah harus ada pihak yang berperan dalam peningkatan mutu tersebut. Peran dalam peningkatan profesionalisme kepala sekolah bekerjasama dengan pengawas sekolah bersama-sama memiliki tanggung jawab terhadap perkembangan sekolah.

Upaya peningkatan keprofesionalan kepala sekolah tidak akan terwujud begitu saja tanpa adanya motivasi dan adanya kesadaran dalam diri kepala sekolah tersebut serta semangat mengabdi yang akan melahirkan visi kelembagaan maupun kemampuan konsepsional yang jelas. Hal ini merupakan faktor yang paling penting sebab tanpa adanya kesadaran dan motivasi semangat mengabdi inilah semua usaha yang dilakukan tidak akan memberikan hasil maksimal dan realisasinya juga tidak akan optimal.

\section{DAFTAR PUSTAKA}

Danim, Sudarwan. (2002). Inovasi Pendidikan dalam Upaya Peningkatan Profesionalisme Tenaga Kependidikan. Bandung: CV. Pustaka Setia.

E. Mulyasa. (2006). Menjadi Kepala Sekolah Profesional. Bandung: PT. Remaja Rosdakarya.

Indarafachrudi, Soekarto. (2006). Bagaimana Memimpin Sekolah yang efektif. Bogor: Ghalia Indonesia.

Kusnandar. (2007). Guru Profesional. Jakarta: PT. Raja Grafindo.

Rahman, dkk. (2006). Peran Strategis Kepala Sekolah dalam Meningkatkan Mutu Pendidikan. Jatinangor: Alqaprint.

Sagala, Syaiful. (2002). Administrasi Pendidikan Kontemporer. Bandung: Alfabeta.

Samsudin, Sadili. (2006). Manajemen Sumber Daya Manusia. Bandung: CV. Pustaka Setia.

Surya, Muhammad. (2007). Organisasi profesi, kode etik dan Dewan Kehormatan Guru.

Toha, Miftah. (2003). Kepemimpinan dalam Manajemen. Jakarta: PT. Raja Grafindo.

Ukas, Maman. (2004). Manajemen. Bandung: Agini.

Uzer, Usman. (2005). Menjadi Guru Profesional. Bandung: Remaja Rosdakarya.

Wahjosumidjo. (2002). Kepemimpinan Kepala Sekolah. Jakarta: PT Raja Grafindo Persada. 